University of Nebraska - Lincoln

DigitalCommons@University of Nebraska - Lincoln

Papers in the Earth and Atmospheric Sciences

Earth and Atmospheric Sciences, Department

\title{
A study of fold characteristics and deformation style using the evolution of the land surface: Zagros Simply Folded Belt, Iran
}

\author{
Caroline M. Burberry \\ University of Nebraska-Lincoln, cburberry2@unl.edu \\ John W. Cosgrove \\ Imperial College London, j.cosgrove@imperial.ac.uk \\ Jian-Guo Liu \\ Imperial College London
}

Follow this and additional works at: https://digitalcommons.unl.edu/geosciencefacpub

Part of the Geology Commons, Geomorphology Commons, Geophysics and Seismology Commons, Hydrology Commons, Stratigraphy Commons, and the Tectonics and Structure Commons

Burberry, Caroline M.; Cosgrove, John W.; and Liu, Jian-Guo, "A study of fold characteristics and deformation style using the evolution of the land surface: Zagros Simply Folded Belt, Iran" (2010). Papers in the Earth and Atmospheric Sciences. 295.

https://digitalcommons.unl.edu/geosciencefacpub/295

This Article is brought to you for free and open access by the Earth and Atmospheric Sciences, Department of at DigitalCommons@University of Nebraska - Lincoln. It has been accepted for inclusion in Papers in the Earth and Atmospheric Sciences by an authorized administrator of DigitalCommons@University of Nebraska - Lincoln. 


\title{
A study of fold characteristics and deformation style using the evolution of the land surface: Zagros Simply Folded Belt, Iran
}

\author{
C. M. Burberry, ${ }^{1,2}$ J. W. Cosgrove, ${ }^{2}$ and J.-G. Liu ${ }^{2}$ \\ 1. Energy \& Geoscience Institute, University of Utah, 423 Wakara Way, Salt Lake City, UT 84102, USA \\ 2. Department of Earth Science and Engineering, Imperial College London, London, SW7 2AZ, UK \\ Corresponding author - C. M. Burberry
}

\begin{abstract}
Deformation styles within a fold-thrust belt can be understood in terms of the spatial organization and geometry of the fold structures. In young fold-thrust belts such as the Zagros, this geometry is reflected topographically by concordant landform morphology. Thus, the distribution of deformation structures can be characterized using satellite image analysis, digital elevation models, the drainage network and geomorphological indicators. The two distinct fold types considered in this study (fault-bend folds and detachment folds) both trending NW-SE, interact with streams flowing NE-SW from the High Zagros Mountains into the Persian Gulf. Multiple abandoned stream channels cross fault-bend folds related to deep-seated thrust faults. In contrast, detachment folds, which propagate laterally relatively rapidly, are characterized by diverted major stream channels and dendritic minor channels at the fold tips. Thus these two fold types can be differentiated on the basis of their geometry (fault-bend folds, being long, linear and asymmetrical, can be distinguished from detachment folds, which tend to be shorter and symmetrical) and on their associated geomorphological structures. The spatial organization of these structures in the Zagros Simply Folded Belt indicates that deformation is the result of the interaction of footwall collapse and the associated formation of long, linear fault-bend folds, and serial folding characterized by relatively short periclinal folds. Footwall collapse occurs first, followed by serial folding to the NE (i.e. in the hanging wall of the fault-bend folds), often on higher detachments within the sediment pile.
\end{abstract}

Fold-thrust belts form in the frontal regions of major contractional orogens, and are frequently important hydrocarbon provinces. Deformation within a fold-thrust belt varies both along and across its strike, on scales of tens to hundreds of kilometers. Variation in deformation style is related to the distribution of major basement faults, the rheological profile of the cover rocks and the depth of the detachment horizon, usually evaporites or over-pressured shales. (Sepehr \& Cosgrove 2004, 2007; Sepehr et al. 2006; Sherkati et al. 2006). Different deformation styles may also be seen in units separated by a detachment horizon, or with different rheologies (Wiltschko \& Chapple 1977; Nickelsen 1988; Sepehr \& Cosgrove 2007).

In this paper, the geometry and geomorphological attributes of the surface folds and the variation in drainage patterns have been used to investigate the distribution of deformation styles and the sequence of deformation within the Zagros Simply Folded Belt. Fold-thrust belts were previously considered to be dominated by detachment folds (Sattarzadeh 1997; Vita-Finzi 2001, 2005). However, seismic studies, neotectonic and geomorphological investigations of the Zagros Belt reveal the presence of numerous fault-bend folds (Berberian \& Qorashi 1994; Talebian \& Jackson 2004). In addition, published cross-sections of the Zagros (McQuarrie 2004; Sepehr \& Cosgrove 2004; Sherkati \& Letouzey 2004; Sherkati et al. 2006; Carruba et al. 2007; Mouthereau et al. 2007; Stephenson et al. 2007) and theoretical studies (Suppe \& Connors 1999) indicate that fold types other than detachment and fault-bend folds can also develop in compressional orogens (Figure 1). Two such fold types are asymmetric detachment folds with thrusts cutting the forelimb, also known as faulted detachment folds, and fault-propagation folds, strongly asymmetric folds developed above a propagating blind fault tip (Rodgers \& Rizer 1981; Mitra 2002; McQuarrie 2004; Sherkati \& Letouzey 2004; Sherkati et al. 2005; Sepehr et al. 2006). Fault-bend folds may also develop from fault-propagation folds (Cosgrove \& Ameen 2000).

As noted above, in fold-thrust belts the fold style is found to be a function of the stratigraphy, depth and the regional tectonic setting. Competing buckling or faulting instabilities determine which fold style 
(a)

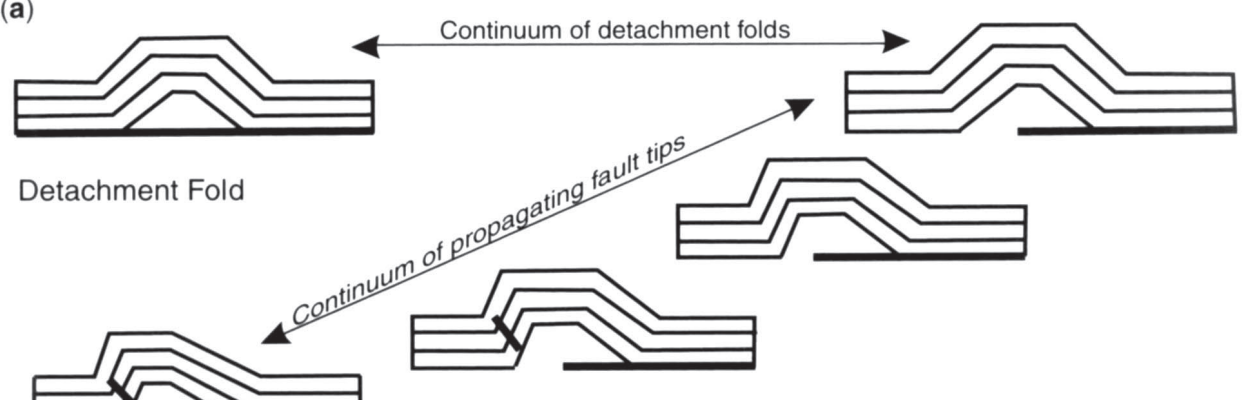

Fault-Propagation Fold

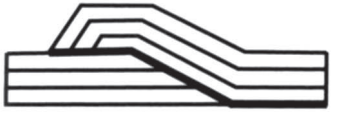

Fault Bend Folds
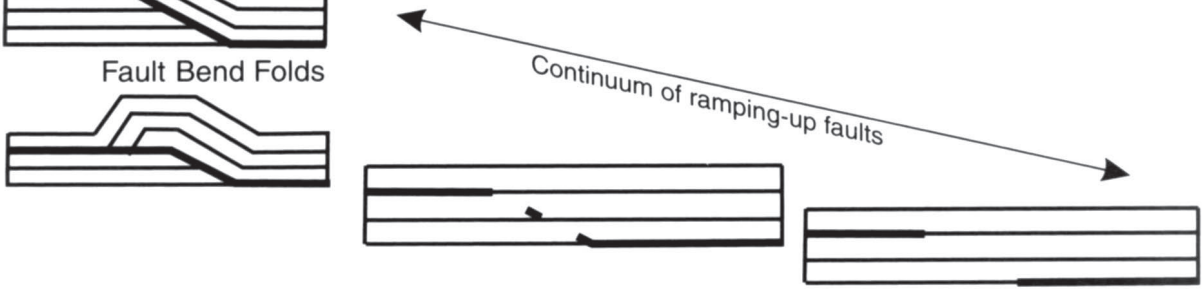

(b)

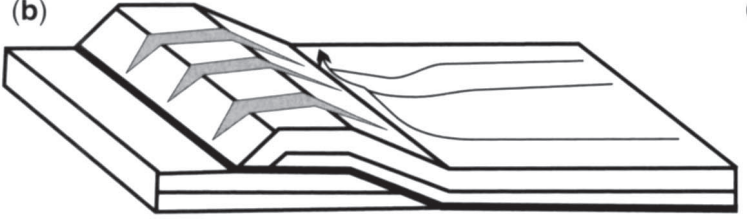

(c)

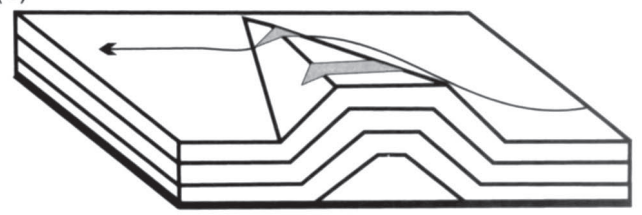

Figure 1. (a) Continua of possible fold geometries in cross-section, including detailed models of the distinct geometries considered in this study, showing characteristic aspect ratio, asymmetry, and drainage diversion; (b) fault-bend fold with a high aspect ratio and long hinge length showing wind gaps and defeated streams diverted parallel to the fold hinge line; (c) detachment fold with low aspect ratio and short hinge length showing a wind gap in the center of the structure and a water gap at the end.

develops, thus distinct fault-bend, fault-propagation and detachment folds may all occur in the same stratigraphy (Jamison 1992). The two distinct fold types considered in this study (fault-bend folds and detachment folds) have characteristic 3D fold geometries and amplification histories. Detachment folds have a low aspect ratio (length:width ratio) and near-perfect symmetry, whereas fault-bend folds have high aspect ratios and a more asymmetric profile (Sattarzadeh 1997; Cosgrove \& Ameen 2000; Blanc et al. 2003). Exceptions to this do occur. For example, where detachment folds interact and link, the aspect ratio is increased (Sattarzadeh et al. 2000; Mitra 2002). In these instances, it is not easy to differentiate between detachment folds and fault-propagation folds (Jamison 1987). Fault-bend folds, however, can be identified from the characteristic broad, asymmetric hinges and long hinge lengths (Suppe 1983).
Periclinal detachment folds have a characteristic amplification pattern predicted from the theoretical analyses of folding, which varies in time and space and is reflected in the fold geometry. As these folds amplify, lateral propagation of the fold tips occurs (Mercier et al. 2007), thus at a specific point on the fold the uplift rate will vary with time and at a particular time the uplift rate will vary along the fold hinge (Cobbold 1976; Summers 1979). As the fold amplifies and begins to lock up, continued shortening may be accommodated by the development of thrust faults in the forelimb, creating asymmetric folds. In contrast, fault-bend folds are formed by uplift above a ramp in a thrust fault and the lateral extent of the fault determines the length of the fold hinge line (Butler 1992). It has been demonstrated that lateral propagation of fault tips and the associated folds can occur (Medwedeff 1992; Delcaillau et al. 1998; Cham- 
pel et al. 2002), but in regions where fault tips interact, this lateral propagation is restricted and faults are seen to maintain near-constant lengths throughout their evolution (Walsh et al. 2002). Significant lateral propagation is not noted in the study area, thus the amplification histories of the two fold-types can be distinguished by their interaction with drainage patterns. In models of fault-bend folding where the fold asymmetry does not increase with time, also assumed in this study, the uplift rate of the fold crest is relatively uniform along the length of the fold hinge line (Wilkerson et al. 1991) but decreases above the fault tips as displacement on the fault dies out (Azor et al. 2002).

Landscapes are often considered to be linear systems with characteristic response times (Beaumont et al. 2000). In fact, a complex feedback system operates, which modifies this simple interaction. Elevation changes related to rifting or to folding drive the evolution of the landscape (Cowie et al. 2006; Whittaker et al. 2007). Drainage systems adapt to changes in the surface slope, recording fold growth and evolution (Jackson et al. 1996). Therefore, the river network is a good indicator of the landform organization, as the points of lowest altitude in the system are embedded into this network. Structural patterns can be seen from statistical analyses of the network (Cudennec \& Fouad 2006). Long-term folding produces topographic features that can affect drainage. Streams are often diverted, frequently with associated ponding of sediment. In regions of active folding, asymmetric patterns in river incision and abandoned alluvial fans also occur (Walker 2006). The relative ages of folds and their associated thrusts within a foldthrust belt can be gained from an examination of the sinuosity of their foreland edge when viewed from above using aerial or satellite images. The amount of incision from stream channels or other subaerial erosion processes produces a fold or mountain front which, when viewed from above, becomes more sinuous with increasing exposure age (Burbank \& Anderson 2001).

Wind and water gaps are produced as streams interact with growing folds (Jackson et al. 1996; Burbank et al. 1999). Water gaps occur where fold uplift rate is slow relative to the stream downcutting rate; for example, at the end of detachment folds. Wind gaps are caused by abandonment of the stream channel where the uplift rate is higher; that is, nearer the central point of a detachment fold. In contrast, the uplift rate along the hinge of a fault-bend fold is relatively uniform and depends on the uplift rate of the underlying block. Thus, streams will either keep pace with uplift, in which case water gaps will occur along the length of the fold, or the stream will be deflected and entrained by the orogen-parallel drainage fabric, resulting in wind gaps along the fold (Burbank \& Pinter 1999; Burbank et al. 1999; Hovius 2000). This current growth of folds in the Zagros Simply Folded Belt is apparent from the deflected and upwarped Roman canal that crosses the Shaur anticline (Lees 1955).

Based on the above differences in geometry and amplification rate recorded in the drainage patterns, this study aims to demonstrate the value of remotely sensed images in the identification of different fold types and deformation styles in inaccessible areas such as the Zagros of Iran. In addition, the use of the fold-front sinuosity index provides a measure of the relative age of these structures.

\section{Regional geology of the Zagros orogenic belt}

The Zagros orogenic belt formed as a result of the collision between the Arabian craton and the Iranian plate (Figure 2). The belt can be divided into the Urumieh-Dokhtar Magmatic arc, Sanandaj-Sirjan zone and the Simply Folded Belt (Alavi 1994). The Simply Folded Belt, which is situated between the High Zagros Fault and the Zagros Frontal Fault, consists of periclinal, en echelon flexural slip folds, which change from gentle and open in the SW to closed and locally overturned in the NE (Alavi 1994). Marked changes in the type and distribution of deformation occur along the belt and these changes coincide with important basement faults such as the north-southtrending Kazerun Fault (Sattarzadeh et al. 2000; Bahroudi \& Talbot 2003; Walpersdorf 2006; Sepehr \& Cosgrove 2007). Since the onset of collision in the Late Cretaceous, the deformation front has migrated from the suture to the current position at present just offshore of the Zagros Frontal Fault, as demonstrated by migrating depocenters deduced from the study of the sedimentary cover sequence and the location of recent earthquake epicenters (Alavi 1994; Talebian \& Jackson 2004).

The $13 \mathrm{~km}$ thick sediment pile that rests on the Precambrian basement can be divided into the lower mobile group (Hormuz Salt), the competent group, the upper mobile group (Miocene evaporites) and the incompetent group (Plio-Pleistocene clastic deposits). The Precambrian Hormuz formation forms the lower detachment, and other important detachment horizons are the Triassic Dashtak Formation and the Miocene Gachsaran Formation (Alavi 2004; Sepehr \& Cosgrove 2007). In the Zagros belt, the resistant OligoMiocene Asmari limestone and the Cretaceous Bangestan group form the whaleback anticlines currently seen at the surface (Blanc et al. 2003; McQuarrie 2004).

Active deformation in the Zagros is dominated by folding above the various subsurface detachments, 


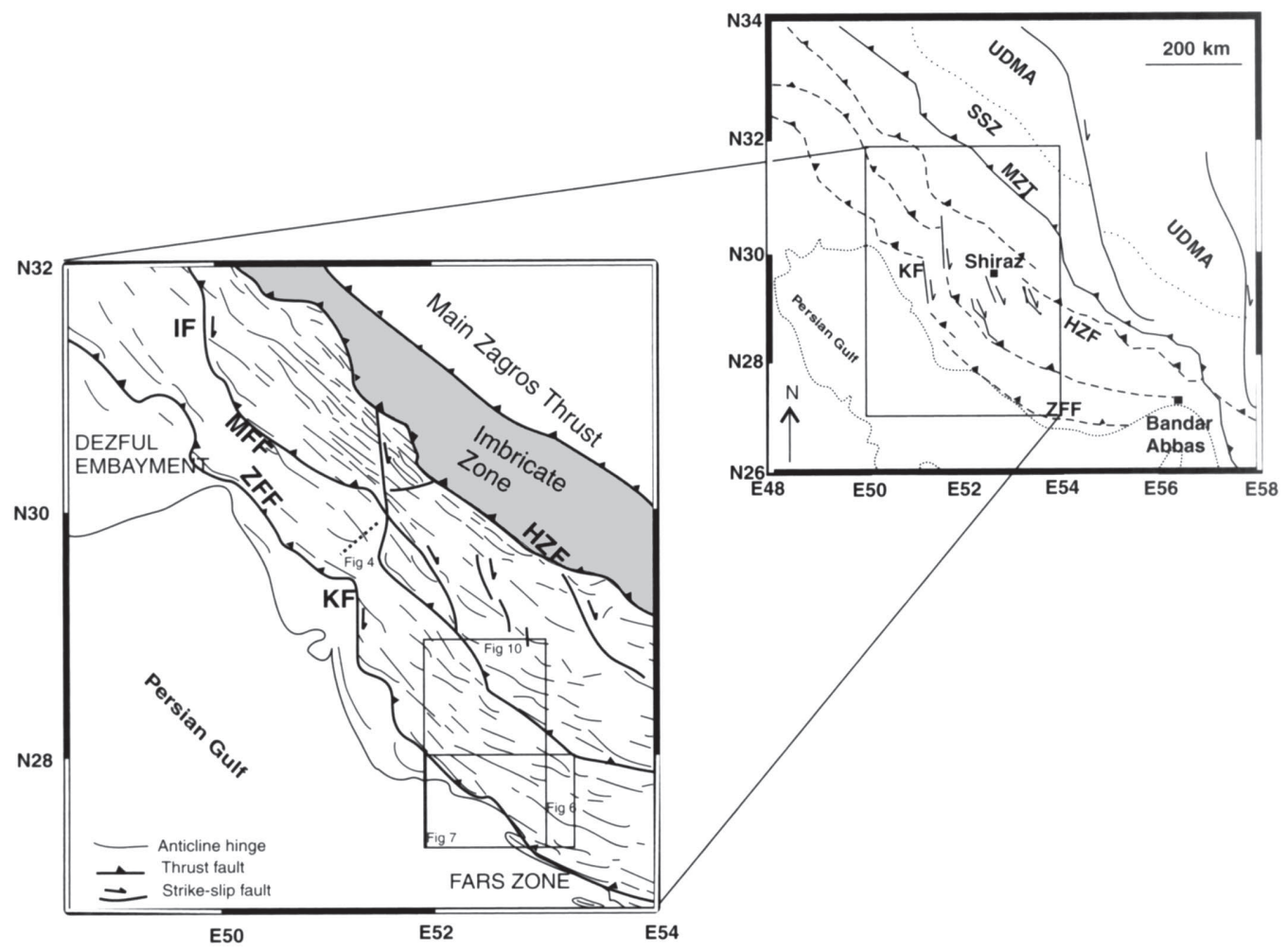

Figure 2. The setting of the Zagros orogenic belt (Molinaro et al. 2005). The High Zagros Fault (HZF) forms the NE limit of the Simply Folded Belt, and the Zagros Frontal Fault (ZFF) marks the edge of the surface expression of deformation. UDMA, Urumieh-Dohktar Magmatic Arc; SSZ, Sanandaj-Sirjan Zone; KF, Kazerun Fault. The locations of the cross-section in Figure 4, as well as boxed areas corresponding to Figures 6, 7, and 10, are marked.

and the variable aspect ratio of the anticlines implies that some are fault bend folds and some are detachment folds (Blanc et al. 2003). The Zagros anticlines show variable vergence, implying the presence of a thick, low-friction décollement beneath the belt. In the Fars zone, this is inferred to be the Hormuz Salt. No outcropping Hormuz Salt is seen in the Dezful Embayment, but the low-angle belt taper, rounded folds and variable vergence imply that there is a thick, low-friction ductile detachment below these folds (Carruba et al. 2007). The Gachsaran Salt acts as a second ductile décollement in many parts of the Fars zone.

Periclinal detachment folds are predominantly found in the Zagros Simply Folded Belt. However, deformation is also accommodated on blind thrusts on the Gachsaran and Hormuz evaporite layers (Berberian 1995) that core asymmetric anticlines. The geometry of many long linear anticlines with a high aspect ratio along the Mountain Front Fault and the Zagros Frontal Fault implies thrust involvement (Sepehr \& Cosgrove 2005). Some thrust-cored folds are inferred to form above reactivated normal faults, which fold the weak, ductile Hormuz Salt. Deformation translates to the competent group above as a brittle thrust (Sattarzadeh et al. 2000). In contrast, linear, en echelon arrays of folds with aspect ratios similar to the detachments folds are linked to basement strike-slip faults (Cosgrove \& Ameen 2000). Finally, the influence of salt diapirs sourced from the basal Hormuz Salt may produce domal features. Faulting and folding are at least in part coseismic, but it is probable that much of the seismic deformation is not accommodated on major emergent faults, but rather by episodic fold growth (Berberian \& Qorashi 1994).

Fold geometry in the Zagros varies significantly, both horizontally and vertically, as a function of the mechanics of the detachment zone and the presence of intermediate décollements (Sherkati et al. 2006). Duplexes and disharmonic folding form where the detachment surface is deep and whaleback anticlines form where the décollement is shallow; for example, on the secondary Triassic Dasktak evaporite décollement in the Fars zone. Variation in folding styles can 
be seen in different segments of the belt, attributed to variable depocenters as major north-south-trending faults dissect the belt (Sepehr \& Cosgrove 2007). Shortening rates are also found to vary across these faults (Walpersdorf 2006). Across-strike variation in the amount of shortening implies that most deformation is located at the foreland of the belt (Oveisi et al. 2007) in contrast to the more widely scattered seismicity, with folds such as the Mand Anticline near the Kazerun Fault accommodating 20-35\% of the shortening across the belt at this point.

\section{Derivation of the drainage network and recognition of landform organization}

The Zagros Simply Folded Belt is eminently suitable for satellite image analysis because of low vegetation coverage and well-exposed outcrops in an arid climate. For this study, a section of the Fars region, to the east of the Kazerun fault zone (Figure 2) has been chosen. In this region, the folds are capped by the Oligocene Asmari limestone and the Hormuz Salt, Dashtak Formation and Gachsaran Formation are the major décollement horizons (Bahroudi \& Koyi 2003; Alavi 2004). All folds investigated in this study have been taken from the Fars region to minimize any variation in deformation style caused by variations in the rheological profile of the cover succession along the strike of the belt. Within the study area, immediately adjacent to the Kazerun fault zone, the shorter wavelength anticlines detach on the Triassic Dashtak evaporites (Sepehr \& Cosgrove 2007).

The two distinct fold types can be recognized based on characteristic drainage pattern diversions, aspect ratio, hinge length and symmetry. Landsat-7 ETM+ images were used to delimit fold shapes and to mark locations and diversions of the stream network. Color composites were created by combining Landsat-7 ETM+ bands 5, 3, 1 as red, green and blue, which highlights variation in lithology and suppresses vegetation (Drury 2001). Carbonate layers appear in pink, here picking out the folds that are capped by the Asmari limestone. Fold axial traces were identified from the closures of the top Asmari marker. Major stream channels have also been identified. In areas of confusion, the concentration of vegetation around streams visible on a 432-RGB image (Sabins 1996) was used to separate stream beds from other features. The visualization of color composites was optimized via contrast enhancement techniques. Interactive contrast enhancement relies on manually adjusting the distribution of the data so that the full value range of the image is used. Another technique removes color bias by balancing the color range between different bands using an algorithm known as balanced contrast enhancement technique (Liu 1991). To clarify the relationship between lithology and topography and to identify wind and water gaps in the folds, the enhanced satellite images were draped over a digital elevation model (DEM) covering the study area N27$30^{\circ}$, E51-54 ${ }^{\circ}$. Lastly, a synthetic river network was generated from the DEM tiles. The algorithm used picks out relative topographic lows and constructs a downslope flow network from these points.

Mio-Pliocene deformation in the Zagros Simply Folded Belt has altered the drainage network by defeating and diverting streams (Molinaro et al. 2005). Water gaps where the stream has cut through the end of the growing fold, and wind gaps where the stream system has been defeated and diverted around the growing fold, were identified by comparing satellite images and the artificial stream network. The artificially generated stream network was compared with the manually picked network. Errors occurred in the region of namakirs (salt glaciers) where the software interpreted the relative topographic low as a stream channel. Once this comparison was completed, a map of the locations of stream diversions and abandoned channels was generated.

Folds identified from satellite image analysis were categorized using geomorphological indices aspect ratio and fold symmetry index (Figure 3) calculated from fold width, hinge length and forelimb width measured off a contour map, generated from the DEM tiles. Both aspect ratio (hinge length : fold width) and fold symmetry index (width of forelimb : half-width) can be used to separate fold types and were calculated for each fold. A perfectly symmetric fold will have a symmetry index of unity, whereas an asymmetric fold will have a lower symmetry and therefore a lower value of the fold symmetry index will be calculated.

(a)

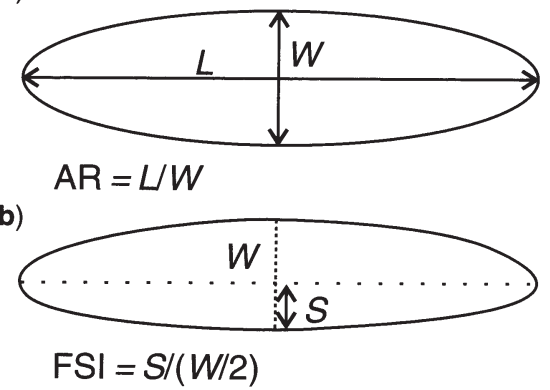

Figure 3. Geomorphological indices used to differentiate fold types: (a) aspect ratio $(L / W)$; (b) fold symmetry index $[S /(W / 2)]$. $S$ is defined as the width of the shorter limb, and for a symmetrical detachment fold the fold symmetry index value will be equal to unity. 

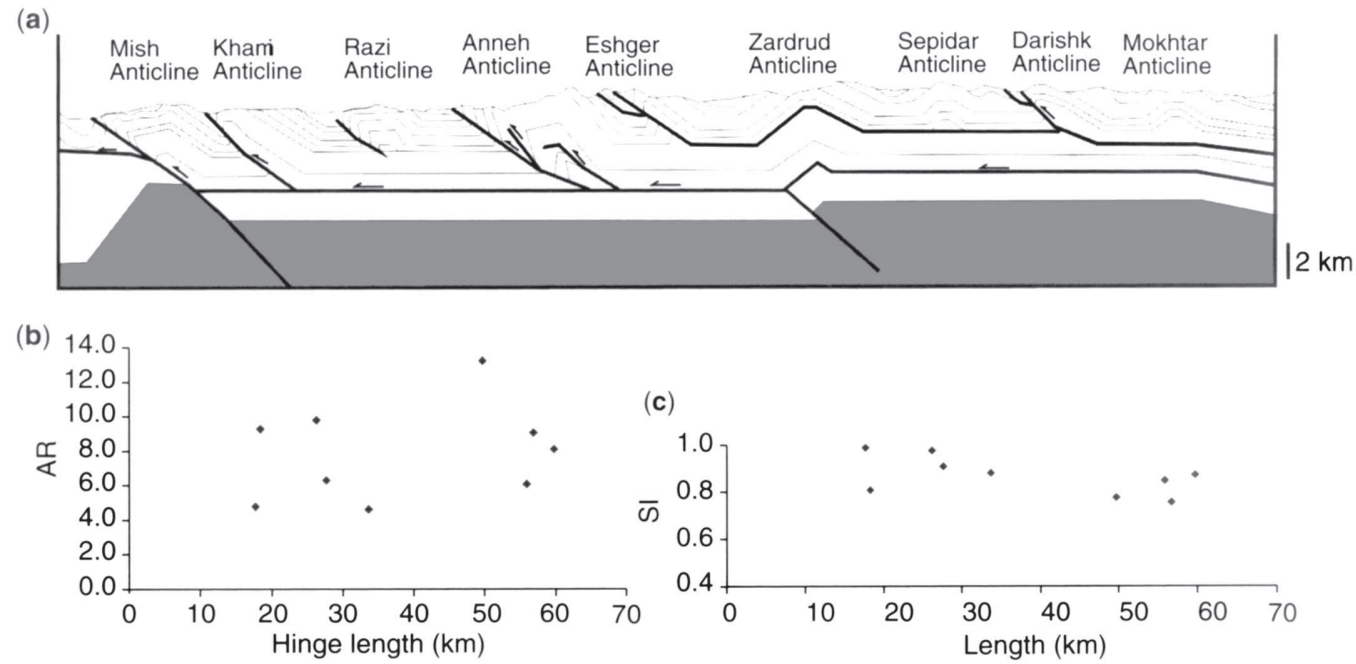

Figure 4. Cross-section (a) of a region where the structure of the folds has been determined by fieldwork (Sepehr \& Cosgrove 2007) and associated geomorphological indices (b) AR and (c) SI, measured from remote data. The folds in the section can be clearly separated into those likely to be fault-bend folds and those likely to be detachment folds. It should be noted that the major basement-involved thrust is the Mountain Front Fault. Detachment folds form behind the thrust, on multiple detachments within the sediment pile. Smaller folds detach on shallower horizons.

The method was tested on a region in the Dezful Embayment, where a structural cross-section has been constructed from field evidence (Sepehr et al. 2006). Four folds in this section (the Mish, Khami, Anneh and Eshger anticlines) have hinge lines longer than $50 \mathrm{~km}$ and corresponding aspect ratios indicate that these folds are fault-bend folds as in the crosssection (Figure 4). Consideration of the symmetry index allows the folds to be clearly divided into two end-member groups, fault-bend folds and detachment folds. Erosion of the land surface will increase the symmetry of the fold structures, as steep slopes are eroded more rapidly than gentle slopes. Over time, therefore, the slopes of the landforms will diverge from the original concordant morphology and tend to a symmetric structure. For folds where there is an independent field dataset of structural dips, the symmetry is shown to be consistently overestimated by about $5 \%$; that is, landform symmetry is higher (fold symmetry index closer to unity) than the symmetry indicated by the dipping beds. This implies that, despite the expected influence of surface processes, the observed variation in fold symmetry index can still be used as an indicator of fold type.

In addition, the relative age of the structures was derived, using the sinuosity of the front of the fold when viewed from above as a proxy. This index is the ratio of the actual mountain front length to the fold hinge length (Figure 5). A higher sinuosity measurement implies a heavily incised fold front and thus an older fold structure (Azor et al. 2002; Silva et al. 2003).

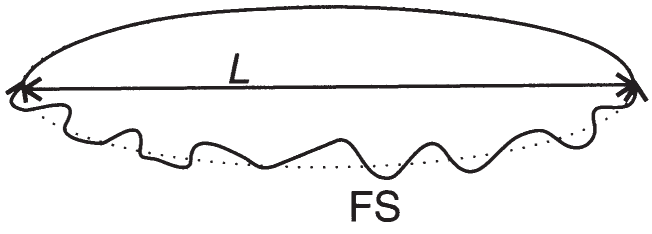

$F F S=F S / L$

Figure 5. A third geomorphological index, fold front sinuosity (FFS), used as a proxy for the age of the fold structure. FFS is calculated as the actual length of the fold front/fold length. Older structures, having been exposed to subaerial weathering processes for longer, will have a higher FFS.

\section{Development of the present-day drainage network}

The pre-folding drainage system is likely to have been a dendritic system (Summerfield 1991) with the dominant direction of flow approximately from NE to SW (i.e. towards the Persian Gulf). The development of NW-SE-trending folds has caused the present drainage pattern to deviate significantly from the original pattern, producing drainage basins that mimic the fold trends. Present-day major streams display a trellis morphology (Figure 6a), with the prominent stream direction parallel to the fold hinges. This drainage morphology modifies the area and shape of the 
(a)
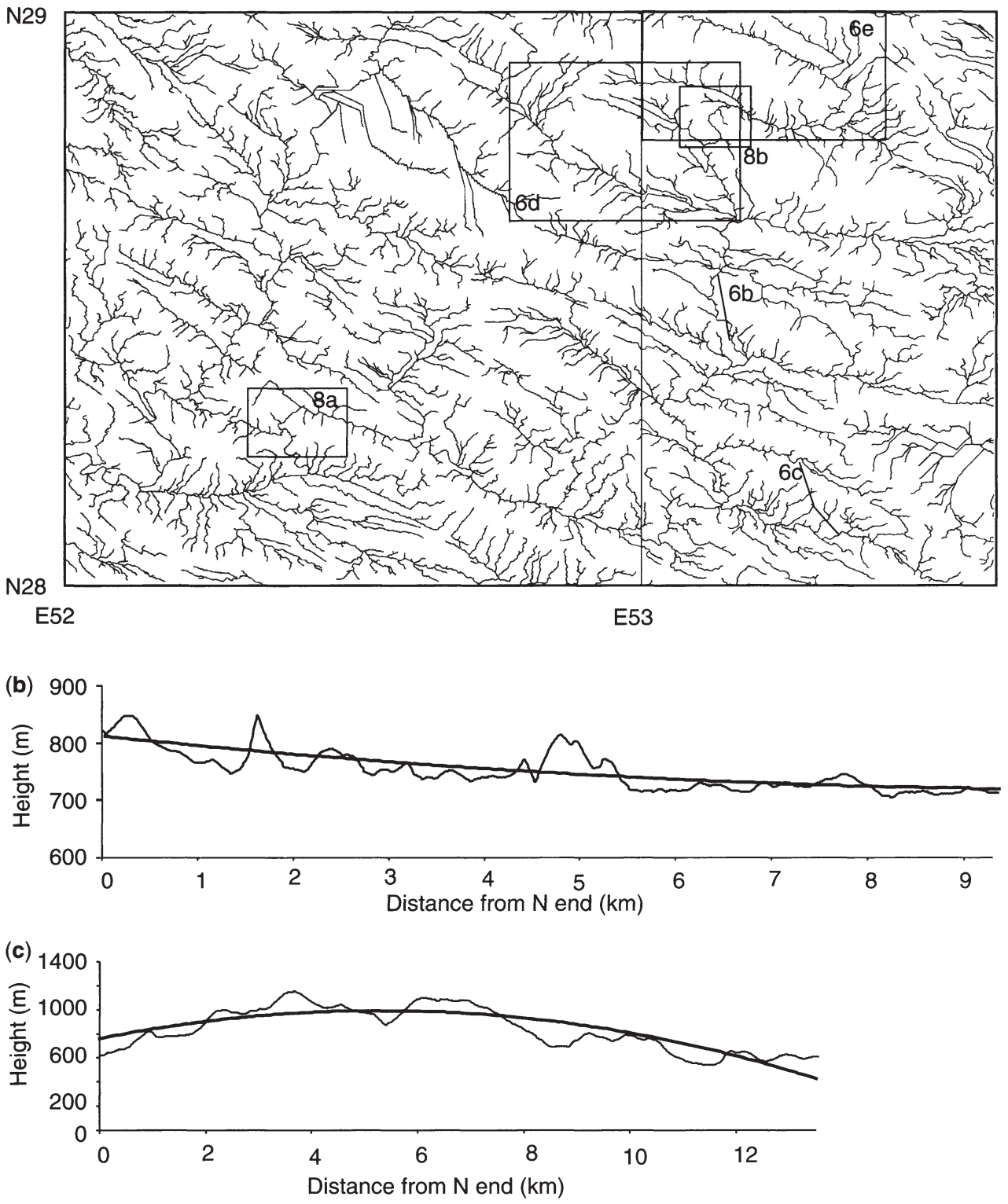

(d)

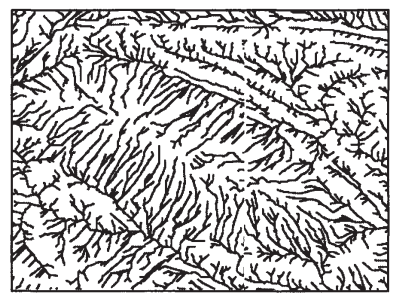

(e)

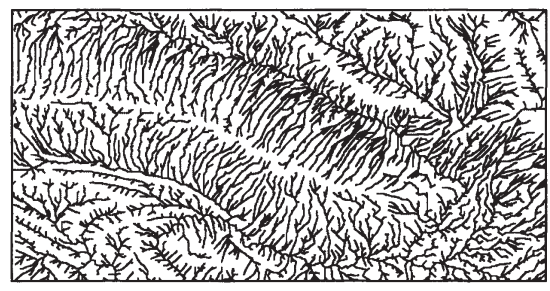

Figure 6. (a) Drainage patterns in the Zagros Simply Folded Belt showing high-order streams displaying a trellis pattern with the prominent direction paralleling the fold hinge lines, with detail of (b) the typical long profile of a water gap, (c) the typical long profile of a wind gap, (d) low-order streams showing a symmetrical pattern around a detachment fold and (e) low-order streams showing an asymmetric pattern around a fault-bend fold. The location of Figure 8a,b is also marked. 


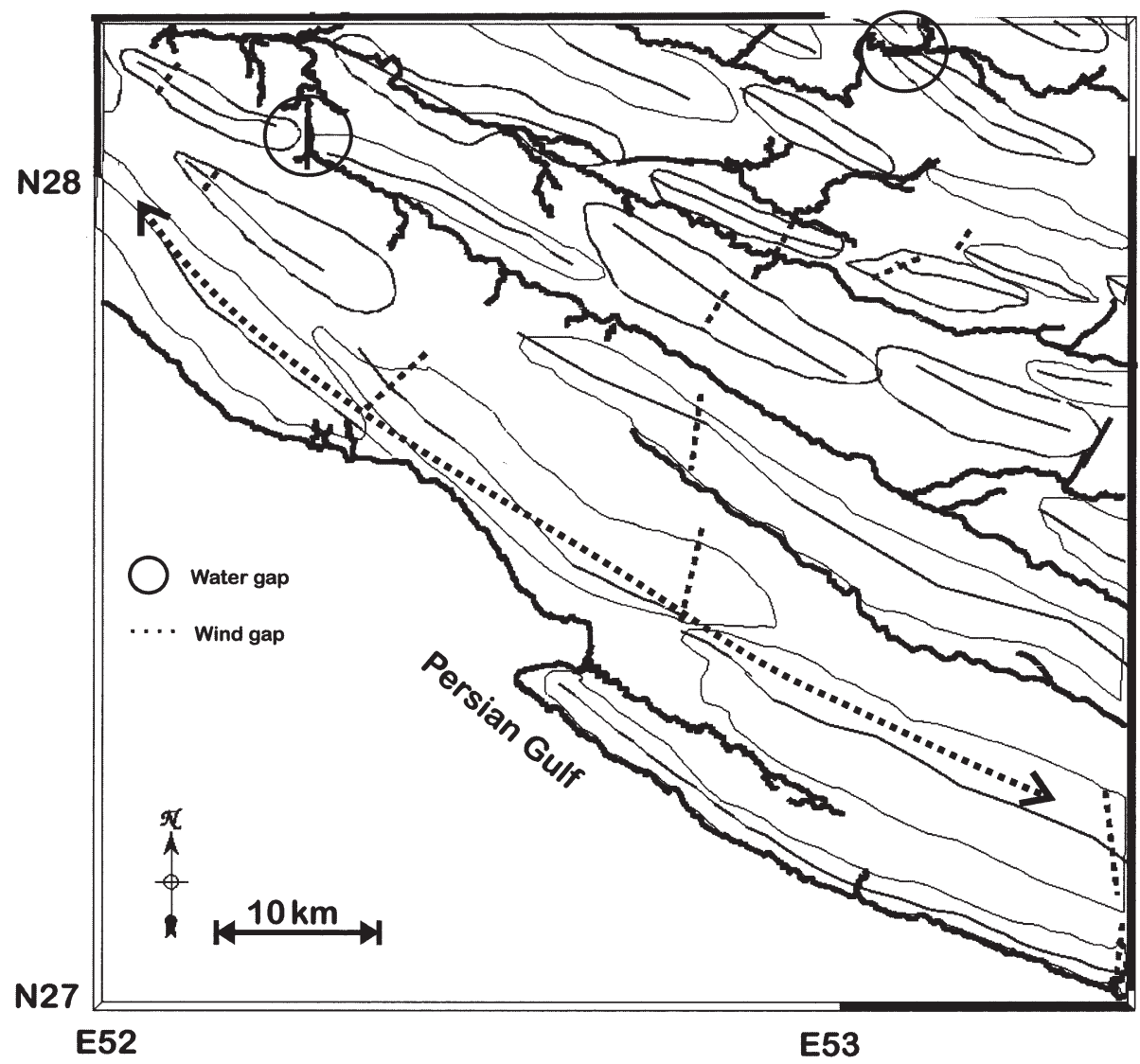

Figure 7. Spatial arrangement of wind and water gaps in the Zagros Simply Folded Belt. Long structures crossed by multiple wind gaps (dotted lines) are considered to be fault-bend folds (e.g. the main fold structures along the coast of the Persian Gulf, the present-day deformation front). In contrast, folds with shorter hinge lines and water gaps at the tips (circled) are considered to be detachment folds.

drainage basins. In some instances, stream channels can be seen to bend around the nose of a fold structure. In many of these cases, the downcutting, erosive power of the stream has been greater than the uplift rate of the fold and a water gap has been incised at the nose of the fold. Water gaps still display the concave-up profile of an equilibrium stream channel (Figure 6b). In contrast, wind gaps may be located on the fold crest, adjacent to the point of significant stream diversion. Wind gaps display a characteristic convex-up profile, as the abandoned stream channel has been uplifted with continuing fold amplification (Figure 6c). Wind gaps are found at the crests of detachment folds because of the high uplift rate in these areas of the fold, and along the full length of faultbend folds, as a result of these folds having a relatively uniform rate of uplift.

Single fold shapes are delimited by minor streams and some asymmetry in the stream network around these landforms can also be recognized. Symmetric stream network patterns are taken as representative of detachment folds (Figure 6d) and asymmetric stream network patterns are found across fault-bend folds (Figure 6e). The watershed of the minor streams is the crest of the landform, in this study taken to be a proxy for the position of the fold crest. Each fold has three distinct morphometric domains within the drainage pattern: a dendritic region towards each fold tip, and a central section where streams flow parallel to dip (Figure 6d, e). The small dendritic tip regions imply limited incorporation of undeformed material into the fold structure, and therefore limited lateral propagation, even for fault-related folds (Walsh et al. 2002).

Spatially, wind and water gaps are not uniformly distributed across the Simply Folded Belt. In the hinterland of the belt, and in the Dezful Embayment, streams are generally observed to be transverse to 
(a)

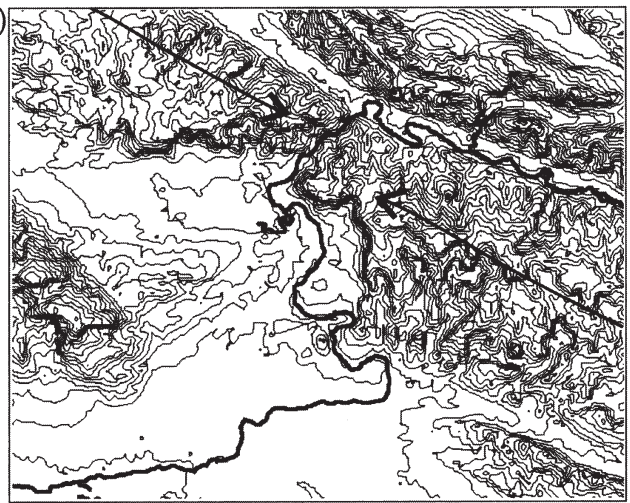

(b)

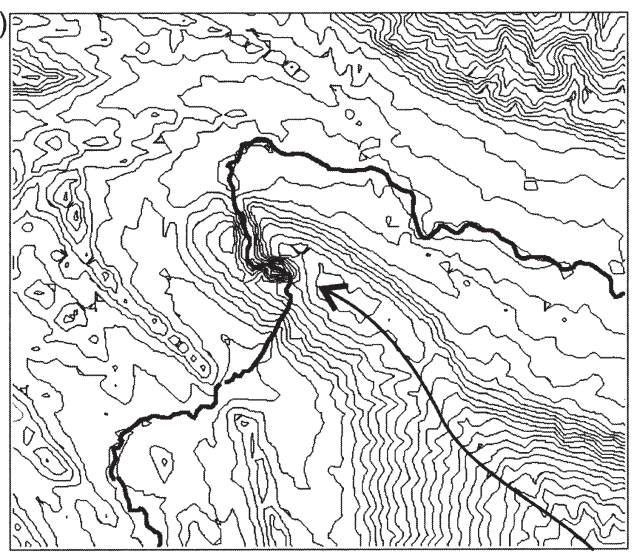

Figure 8. (a) Contour map of linked fold structures in the Zagros Simply Folded Belt, showing interaction of fold tips and a river channel incised at the topographic low, in contrast to (b) the narrow canyon of a water gap created by river incision at the tip of a growing fold. The locations of these figures are shown in Figure 6.

the structures (Oberlander 1985). In the foreland, in the Fars region, distinct fold structures are crossed by multiple wind gaps (Figure 7) and many folds have water gaps at the tips. Multiple wind gaps crossing a long fold crest imply uniform and rapid uplift along this fold structure, causing abandonment and diversion of multiple stream channels. This in turn implies that these folds are fault-bend folds. Fault-bend folds can therefore be characterized by the presence of multiple crosscutting wind gaps along the hingeline of the structure.

Drainage can be further distorted from a general dendritic pattern by folds linking with neighboring structures. In this case, the river system appears to cut across the axial trace of a fold but closer inspection reveals that there is a topographic low at the point where the two fold noses interact (Figure 8a). The same process has been documented in other ac- tively deforming regions (Jackson et al. 1996). A river that has been diverted around a growing fold is unlikely to be further diverted given the low dips and correspondingly low amplification rates of the folds in the linking region, and the morphology is markedly different from that of a typical water gap (Figure $8 b)$.

\section{Geomorphological analysis of the fold structures}

Fold axial traces are seen to trend consistently NW-SE in this section of the Simply Folded Belt. In some areas, the fold geometry is altered by the proximity of major thrust faults. A large variation can be found in fold hinge length, with the shortest folds having a hinge length around $10 \mathrm{~km}$ and the longest around $100 \mathrm{~km}$.

Each fold was classified using the geomorphological indices aspect ratio and fold symmetry index, together with the hinge length and the locations of wind and water gaps. The fold population in the Zagros can be broadly separated into two groups based on the relationship between length and aspect ratio. When these indices are compared with the length of the hinge line, folds with a hinge length greater than about $60 \mathrm{~km}$ show a linear relationship between aspect ratio and the hinge length (Figure 9a) Many of these folds are also distinctly asymmetric (Figure 9b). Detachment folds are seen to cluster with aspect ratios less than 10, and hinge lengths less than $60 \mathrm{~km}$ (Figure 9a) and can also be seen to have a symmetry close to unity (Figure 9b). These folds do not display the linear relationship between aspect ratio and fold length. These two datasets are interpreted as representative of two distinct folding processes operating in the region, forming the two distinct fold types. Fault-bend folds, having no lateral propagation of the fault tips, as described above, show a linear relationship between the aspect ratio and the hinge length. A distinct cluster of detachment folds can be clearly marked, but the spread in the dataset implies that this cluster may include the other fold geometries as discussed above. The linear relationship given for the fault-bend fold dataset could potentially be extended into the clustered region, raising questions about the minimum and maximum geometrically and kinematically viable hinge lengths for the two distinct fold types that have yet to be satisfactorily answered.

Asymmetric detachment folds and fault-propagation folds form another significant class of folds, which can be identified by the combination of low symmetry and a short hinge length. The dominant vergence of the asymmetric detachment folds is SW, 

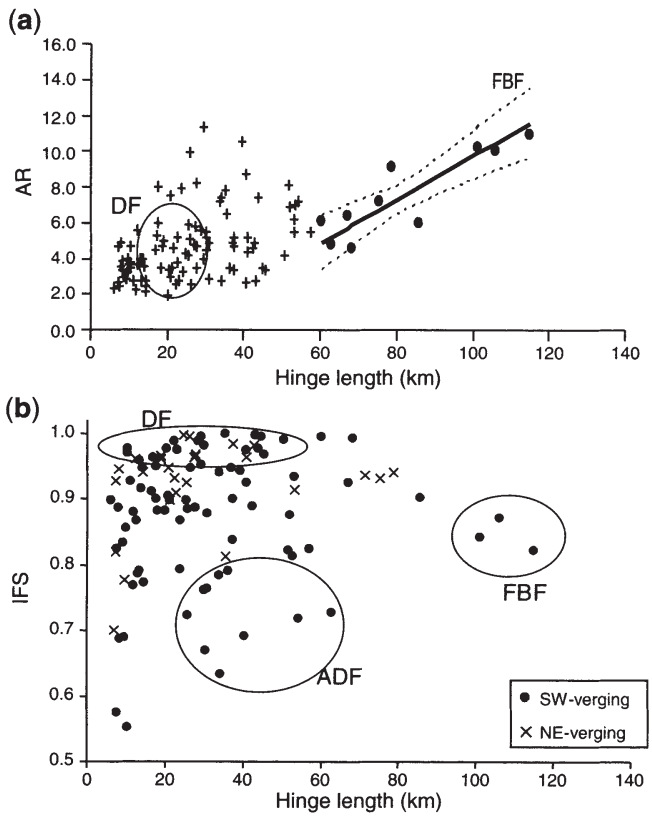

Figure 9. The separation of detachment and fault-bend folds by comparison between hinge length and (a) aspect ratio and (b) fold symmetry index. The large cluster of data marked at low hinge lengths corresponds to detachment folds (DF). The data points along the trendline (with $95 \%$ confidence interval marked) are identified as fault-bend folds (FBF). A third cluster marked by short hinge lengths but low symmetry is likely to be asymmetric detachment folds (ADF). Folds generally verge SW but those structures with a NE vergence are marked by crosses in (b).

although a minority verge to the NW. These folds often have a lower symmetry than the fault-bend folds and can be identified as a third, less well-defined cluster on a graph of symmetry v. hinge length (Figure $9 b)$. Structures with an aspect ratio close to unity are folds related to salt domes rather than true detachment folds.

\section{Spatial arrangement and relative age of fold structures}

Folds with short hinge lengths and low aspect ratios were found to be spatially coincident with the locations of diverted streams and water gaps at the fold tips and were inferred to be detachment folds. In turn, anomalously long, high aspect ratio, asymmetric folds identified from geomorphological indices are also the fold structures cross-cut by multiple wind gaps, confirming that these are fault-bend folds. The majority of long fault-bend folds are found to lie directly above the outcropping major thrusts within the Zagros Simply Folded Belt, with the largest, prominent fault-bend folds along the Zagros Frontal Fault, the terrestrial deformation front (Figs $1 \& 10$ ). Detachment folds cluster between the major thrusts, and more asymmetric detachment folds are often found close to the fault-bend folds.

The spatial variation in the locations of fault-bend folds and detachment folds is also spatially coincident with the location of the major topographic steps in the landscape (McQuillan 1973; Sattarzadeh 1997; McQuarrie 2004; Mouthereau et al. 2006). In the longwave topographic signal, the major steps can be seen corresponding to the Mountain Front Fault and the Zagros Frontal Fault. Fault-bend folds are seen to lie at the locations of the major steps, suggesting that these folds are related to the major thrust faults.

Folds in the eastern section of the study area, away from the influence of lateral ramps in the thrust faults and major north-south-trending faults such as the Kazerun Fault, show a broadly linear decrease in relative age from the High Zagros Fault to the deformation front of the belt (Figure 11). Superimposed on this trend are a number of fold structures with older relative ages than expected. These lie close to the positions of the thrust faults and are interpreted to indicate the structures formed by footwall collapse as the deformation front migrates to the foreland. A peak in the fold front sinuosity (FFS) between the major thrust faults corresponds to a branch line thrust of the rear thrust, the High Zagros Fault.

The wavelength of a detachment fold structure is determined by the depth to the detachment, with lower wavelength folds detaching on higher horizons within the sedimentary succession. In the Zagros Simply Folded Belt, the detachment fold amplitude structures are consistently an order of magnitude smaller than the fault bend fold amplitudes, indicating that these folds are detaching on an intermediate décollement level rather than the major basal décollement. Variation in shortening occurs above and below intermediate detachment horizons and detachment folds decrease in amplitude towards the SW with each discrete block. A forward-developing sequence of fold initiation is thus inferred, with a corresponding decrease in the percentage shortening and a general drop in elevation. In addition, the FFS index indicates that serial detachment folding is occurring in discrete blocks between thrusts that have formed sequentially by footwall collapse.

Movement up a thrust ramp creates a fault-bend fold. Compressive stresses build up, leading to serial folding in the cover behind the fault-bend fold. Voids are filled by the ductile detachment material. The 
(a)

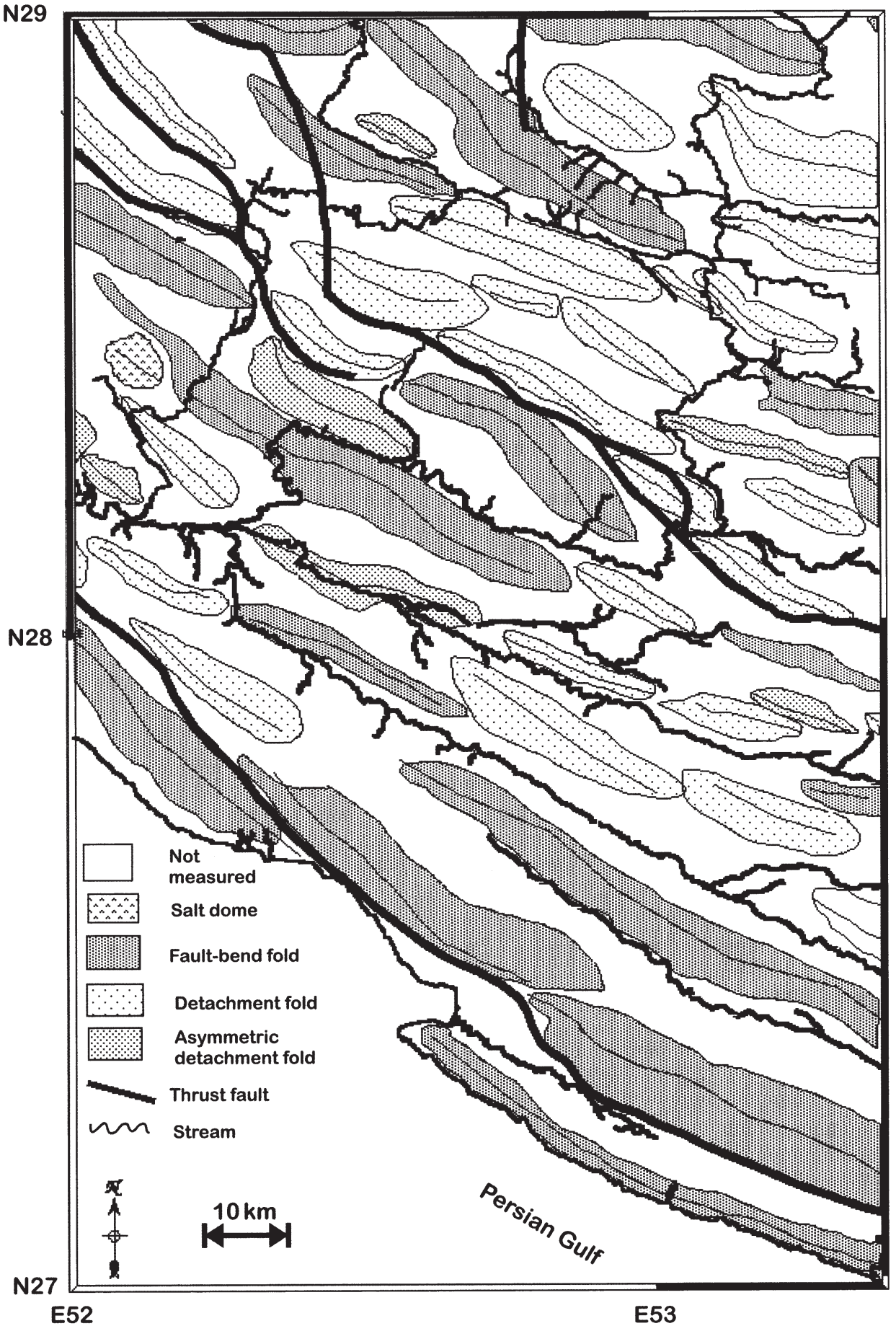

Figure 10. Spatial arrangement of the end-member fold types in the Zagros Simply Folded Belt: (a) shaded by fold type and (b) showing both an actual view of the surface and a 3D section of the belt. Long fault-bend folds are found associated with the major thrust faults and detachment folds are found in discrete blocks between these thrust slices. The base image is a Landsat-7 ETM+ false color composite, draped over an SRTM DEM. The full shaded map has been published by Burberry et al. (2007). 
(b)

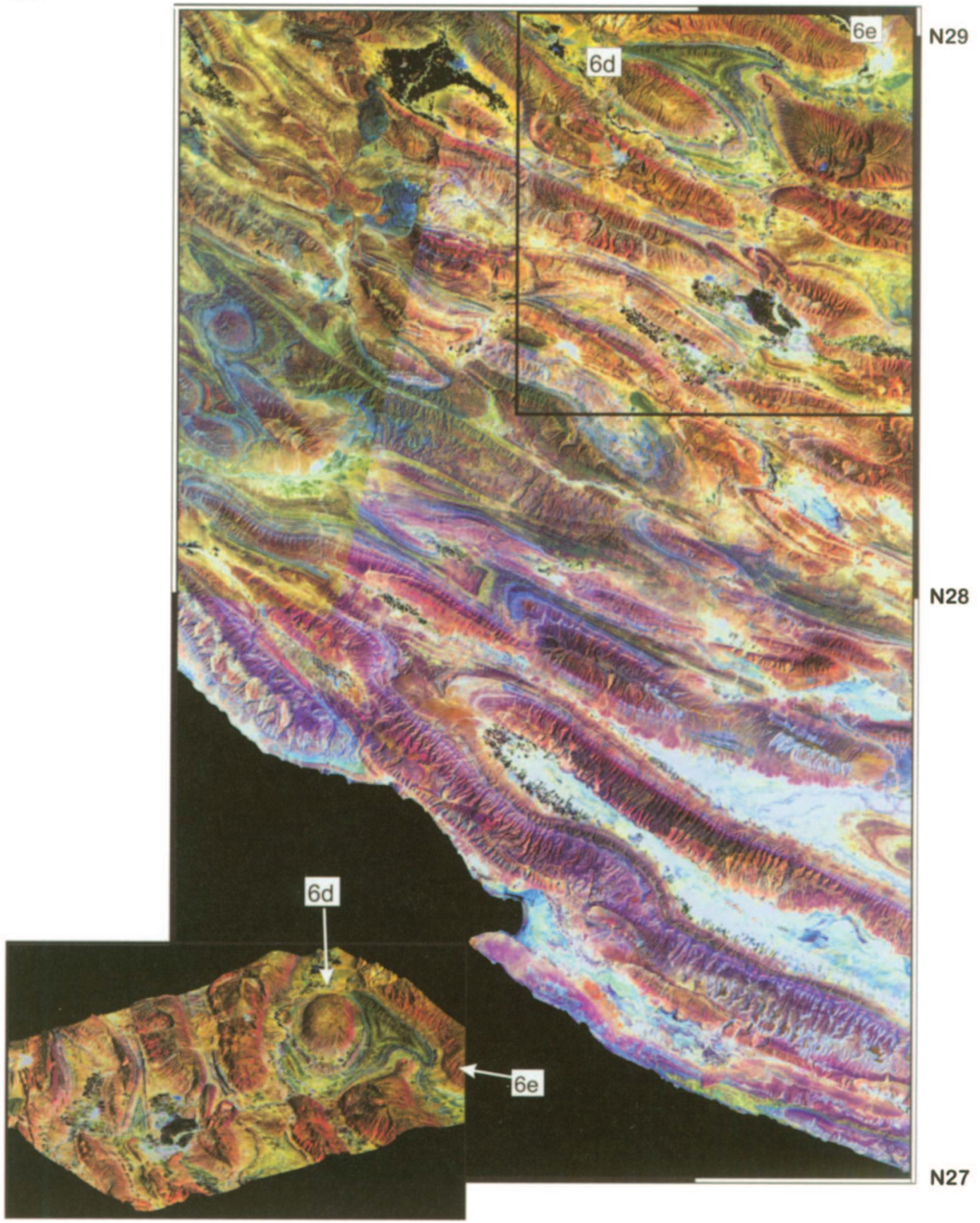

Figure 10. (continued)

presence of asymmetric, detachment folds implies that additional shortening may have been accommodated by thrust development in the core of detachment folds. Eventually, deformation of the block re- quires stresses in excess of those required to create a new footwall thrust. The original thrust is abandoned, the footwall collapses and the process repeats (Figure 12). 


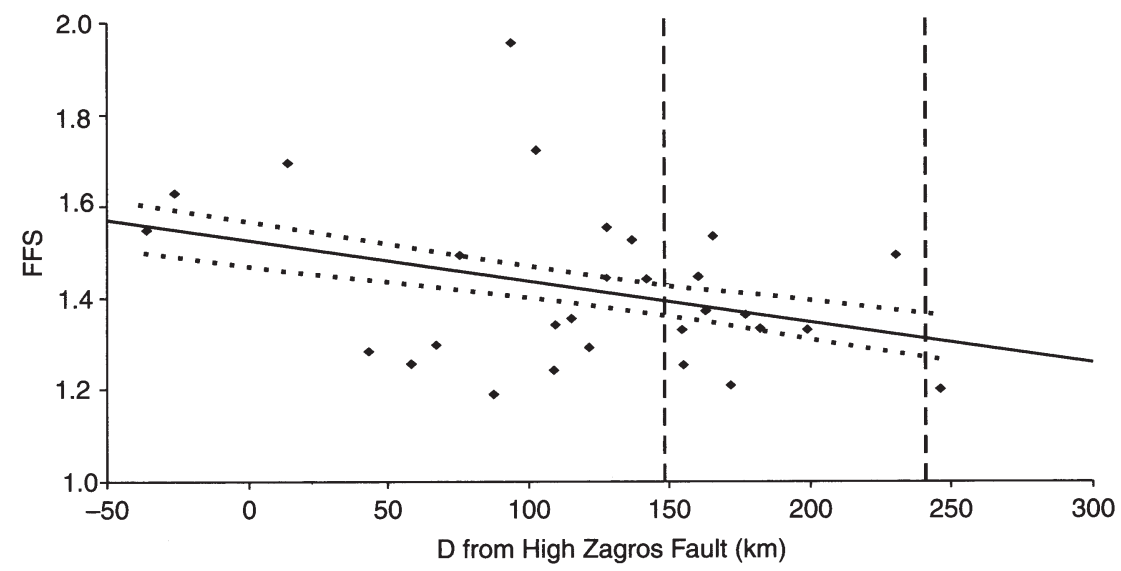

Figure 11. Relative age of fold structures within the Zagros Simply Folded Belt, decreasing from the hinterland towards the foreland. Anomalously old folds are located close to the thrust faults (marked by vertical dashed lines) implying the interaction of footwall collapse and subsequent serial folding as the deformation front migrates to the SW.

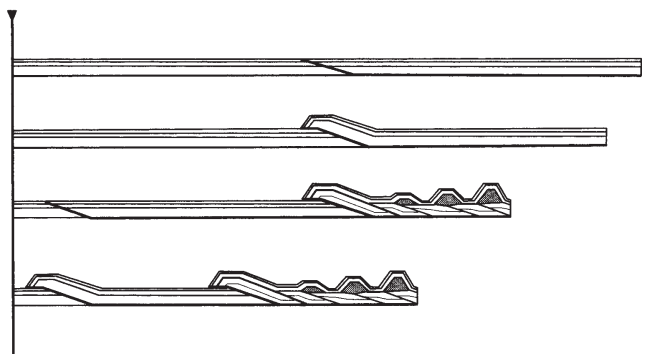

Figure 12. Model of combined brittle and ductile deformation by both footwall collapse and serial folding in the Zagros Simply Folded Belt. Detachment folds form on higher décollement horizons within the sediment pile, whereas major thrust faults detach on the basal Hormuz Salt formation. Voids created by the formation of detachment folds are filled by flow of material from the décollement horizon, and the lower portion of the sediment pile must also undergo shortening, potentially on imbricate thrust faults, so that the section balances.

\section{Conclusions}

It has been proposed that the different fold types that develop in a fold-thrust belt (primarily detachment folds and fault-bend folds) can be identified on satellite images using their geometry (specifically aspect ratio and symmetry) and interaction with drainage patterns. Fault-bend folds are characteristically asymmetric with long hinge lines and high aspect ratios, and detachment folds are characteristically symmetric and have shorter hinge lines and lower aspect ratios. Remote sensing and the analysis of satellite images have been used to distinguish between fold types in the Zagros fold-thrust belt and help elucidate the se- quence of their development, using the geomorphological indices described above. This study demonstrates that the two distinct fold types described can be differentiated with some statistical confidence.

In addition, the spatial organization of the two distinct fold types (three ridges of fault-bend folds, separated by two regions of detachment folds) reveals the process by which the deformation front has migrated to the SW, away from the collision zone. The topographic ridges representing the fault-bend folds, which are spatially associated with the major thrust faults (the High Zagros Fault, the Mountain Front Fault and the Zagros Frontal Fault), formed sequentially by footwall collapse as the deformation front migrated towards the foreland basin.

It has previously been suggested that the detachment folds within a fold-thrust belt form in a nonsynchronous serial fashion linked to the propagation of deformation away from the collision zone towards the foreland (Blay et al. 1977; Vita-Finzi 2005). This study reveals that, within the Zagros Simply Folded Belt, the migration of deformation involves the interaction of both footwall collapse and the simplified serial folding model. As the fault-bend folds amplified, propagation of the thrusts became progressively more difficult and the compressive stress rose. This resulted in the development of detachment folds by serial folding on higher detachment horizons in the cover behind the fault-bend folds, which acted as buttress structures.

Acknowledgments - This research was supported by a Janet Watson Scholarship from the Department of Earth Science and Engineering, Imperial College London. We thank J. Carter (Imperial College) for assistance with the statistical analyses of the data. Satellite data used in this study 
were sourced from the Global Landcover Facility, http:// www.landcover.org. The DEM tiles used in this study were sourced from the NASA Land Processes Distributed Active Archive Center ( $\mathrm{ftp}: / / \mathrm{e} 0$ srp01u.ecs.nasa.gov/srtm/ ). We gratefully acknowledge the comments of P. Van der Beek and E. A. Keller, whose contributions significantly improved the original manuscript.

\section{References}

Alavi, M. 1994. Tectonics of the Zagros orogenic belt of Iran: New data and interpretations. Tectonophysics, 229,211-238.

Alavi, M. 2004. Regional stratigraphy of the Zagros fold-thrust belt of Iran and its proforeland evolution. American Journal of Science, 304, 1-20.

Azor, A., Keller, E. A. \& Yeats, R. S. 2002. Geomorphic indicators of active fold growth: South Mountain-Oak Ridge anticline, Ventura basin, southern California. Geological Society of America Bulletin, 114, 745-753.

Bahroudi, A. \& Koyi, H. A. 2003. Effect of spatial distribution of Hormuz salt on deformation style in the Zagros fold and thrust belt: An analogue modelling approach. Journal of the Geological Society, London, 160, 719-733.

Bahroudi, A. \& Talbot, C. J. 2003. The configuration of the basement beneath the Zagros Basin. Journal of Petroleum Geology, 26, 257-282.

Beaumont, C., Kooi, H. \& Willett, S. D. 2000. Coupled tectonic-surface process models with applications to rifted margins and collisional orogens. In: Summerfield, M. A. (ed.) Geomorphology and Global Tectonics. Wiley, New York, 29-55.

Berberian, M. 1995. Master blind thrust faults hidden under the Zagros Folds - active basement tectonics and surface morphotectonics. Tectonophysics, 241, 193-224.

Berberian, M. \& Qorashi, M. 1994. Coseismic fault-related folding during the South Golbaf earthquake of November 20, 1989, in southeast Iran. Geology, $22,531-534$.

Blanc, E. J. P., Allen, M. B., Inger, S. \& Hassani, H. 2003. Structural styles in the Zagros Simple Folded Zone, Iran. Journal of the Geological Society, London, 160, 401-412.

Blay, P., Cosgrove, J. W. \& Summers, J. M. 1977. An experimental investigation of the development of structures in multilayers under the influence of gravity. Journal of the Geological Society, London, 133, 329-342.
Burbank, D. W. \& Anderson, R. S. 2001. Tectonic Geomorphology. Blackwell Science, Oxford.

Burbank, D. W. \& Pinter, N. 1999. Landscape evolution: The interactions of tectonics and surface processes. Basin Research, 11, 1-6.

Burbank, D. W., McLean, J. K., Bullen, M., Abdrakhmatov, K. Y. \& Miller, M. M. 1999. Partitioning of intermontane basins by thrust-related folding, Tien Shan, Kyrgyzstan. Basin Research, 11, 75-92.

Burberry, C. M., Cosgrove, J. W. \& Liu, J. G. 2007. Stream network characteristics used to infer the distribution of fold types in the Zagros Simply Folded Belt, Iran. Journal of Maps, Student Edition, 2007, 32-45.

Butler, R. W. H. 1992. Structural evolution of the western Chartreuse fold and thrust system, NW French Subalpine chains. In: McClay, K. R. (ed.) Thrust Tectonics. Chapman \& Hall, London, 287-298.

Carruba, S., Perotti, C. R., Buonaguro, R., Calabro, R., Carpi, R. \& Naini, M. 2007. Structural pattern of the Zagros fold and thrust belt in the Dezful Embayment (SW Iran). In: Mazzoli, S. \& Butler, R. W. H. (eds.) Styles of Continental Contraction. Geological Society of America, Special Papers, 414, 11-32.

Champel, B., Van Der Beek, P., Mugnier, J. L. \& Leturmy, P. 2002. Growth and lateral propagation of fault-related folds in the Siwaliks of western Nepal: Rates, mechanisms, and geomorphic signature. Journal of Geophysical Research - Solid Earth, 107, doi: 10.1029/2001JB000578.

Cobbold, P. R. 1976. Fold shapes as functions of progressive strain. Philosophical Transactions of the Royal Society of London, Series A, 283, 129-138.

Cosgrove, J. \& Ameen, M. 2000. A comparison of the geometry, spatial organisation and fracture patterns associated with forced folds and buckle folds. In: Cosgrove, J. W. \& Ameen, M. S. (eds.) Forced Folds and Fractures. Geological Society, London, Special Publications, 169, 7-21.

Cowie, P. A., Attal, M., Tucker, G. E., Whittaker, A. C., Naylor, M., Ganas, A. \& Roberts, G. P. 2006. Investigating the surface process response to fault interaction and linkage using a numerical modelling approach. Basin Research, 18, 231-266.

Cudennec, C. \& Fouad, Y. 2006. Structural patterns in river network organization at both infra- and supra-basin levels: The case of a granitic relief. Earth Surface Processes and Landforms, 31, 369-381.

Delcaillau, B., Deffontaines, B., et al. 1998. Morphotectonic evidence from lateral propagation of an ac- 
tive frontal fold; Pakuashan anticline, foothills of Taiwan. Geomorphology, 24, 263-290.

Drury, S. 2001. Image Interpretation in Geology. Nelson Thornes, Cheltenham.

Hovius, N. 2000. Macroscale process systems of mountain belt erosion. In: Summerfield, M. A. (ed.) Geomorphology and Global Tectonics. Wiley, New York, 77-105.

Jackson, J., Norris, R. \& Youngson, J. 1996. The structural evolution of active fault and fold systems in central Otago, New Zealand: Evidence revealed by drainage patterns. Journal of Structural Geology, $18,217-234$

Jamison, W. R. 1987. Geometric analysis of fold development in overthrust terranes. Journal of Structural Geology, 9, 207-219.

Jamison, W. R. 1992. Stress controls on fold-thrust style. In: McClay, K. R. (ed.) Thrust Tectonics. Chapman \& Hall, London, 155-164.

Lees, G. M. 1955. Recent earth movements in the Middle East. Geologische Rundschau, 43, 221-226.

Liu, J. G. 1991. Digital image processing/or automatic lithological mapping using Landsat TM imagery. Imperial College, London.

McQuarrie, N. 2004. Crustal scale geometry of the Zagros fold-thrust belt, Iran. Journal of Structural Geology, 26, 519-535.

McQuillan, H. 1973. Small-scale fracture density in Asmari-Formation of Southwest Iran and its relation to bed thickness and structural setting. AAPG Bulletin, 57, 2367-2385.

Medwedeff, D. A. 1992. Geometry and kinematics of an active laterally propagating wedge thrust, Wheeler Ridge, California. In: Mitra, S. \& Fisher, G. W. (eds.) Structural Geology of Fold-Thrust Belts, John Hopkins University Press, Baltimore, 3-28.

Mercier, E., Rafani, S. \& Ahmadi, R. 2007. Fold kinematics in fold-thrust belts: The hinge migration question. In: Lacombe, O., Lavé, J., Roure, F. \& Vergés, J. (eds.) Thrust Belts and Foreland Basins. Springer, Berlin, 135-147.

Mitra, S. 2002. Structural models of faulted detachment folds. AAPG Bulletin, 86, 1673-1694.

Molinaro, M., Leturmy, P., Guezou, J. C., Frizon de Lamotte, D. \& Eshraghi, S. A. 2005. The structure and kinematics of the southeastern Zagros fold-thrust belt, Iran: From thin-skinned to thick-skinned tectonics. Tectonics, 24, doi: 10.1029/2004TC001633.

Mouthereau, F., Lacombe, O. \& Meyer, B. 2006. The
Zagros folded belt (Fars, Iran): Constraints from topography and critical wedge modelling. Geophysical Journal International, 165, 336-356.

Mouthereau, F., Lacombe, O., Tensi, J., Bellah-Sen, N., Kargar, S. \& Amrouch, K. 2007. Mechanical constraints on the development of the Zagros Folded Belt (Fars). In: Lacombe, O., Lavé, J., Roure, F. \& Vergés, J. (eds.) Thrust Belts and Foreland Basins from Fold Kinematics to Hydrocarbon Systems. Frontiers in Earth Sciences. Springer, Berlin, 247-266.

Nickelsen, R. P. 1988. Structural evolution of folded thrusts and duplexes on a first-order anticlinorium in the Valley and Ridge Province of Pennsylvania. In: Mitra, G. \& Wojtal, S. (eds.) Geometries and Mechanism of Thrusting, with Special Reference to the Appalachians. Geological Society of America, Special Papers, 222, 89.

Oberlander, T. M. 1985. Origin of drainage transverse to structures in orogens. Tectonic geomorphology. Binghamton Symposia in Geomorphology, 15, 155.

Oveisi, B., Lavé, J. \& Van der Beek, P. A. 2007. Rates and processes of active folding evidenced by Pleistocene terraces at the central Zagros front, Iran. In: Lacombe, O., Lavé, J., Roure, F. \& Vergés, J. (eds.) Thrust Belts and Foreland Basins. Springer, Berlin, 267-287.

Rodgers, D. A. \& Rizer, W. D. 1981. Deformation and secondary faulting near the leading edge of a thrust fault. In: McClay, K. R. \& Price, N. J. (eds.) Thrust and Nappe Tectonics. Geological Society, London, Special Publications, 9, 65-77.

Sabins, F. F. 1996. Remote Sensing Principles and Interpretation. W. H. Freeman, New York.

Sattarzadeh, Y. 1997. Active tectonics in the Zagros Mountains, Iran. PhD thesis, Imperial College, London.

Sattarzadeh, Y., Cosgrove, J. \& Vita-Finzi, C. 2000. The Interplay of faulting and folding during the evolution of the Zagros deformation belt. In: Cosgrove, J. W. \& Ameen, M. S. (eds.) Forced Folds and Fractures. Geological Society, London, Special Publications, 169, 187-196.

Sepehr, M. \& Cosgrove, J. W. 2004. Structural framework of the Zagros Fold-Thrust Belt, Iran. Marine and Petroleum Geology, 21, 829-843.

Sepehr, M. \& Cosgrove, J. W. 2005. Role of the Kazerun Fault Zone in the formation and deformation of the Zagros Fold-Thrust Belt, Iran. Tectonics, 24, doi: 10.1029/2004TC001725. 
Sepehr, M. \& Cosgrove, J. W. 2007. The role of major fault zones in controlling the geometry and spatial organisation of structures in the Zagros Fold-Thrust Belt. In: Ries, A. C., Butler, R. W. H. \& Graham, R. H. (eds.) Deformation of the Continental Crust: The Legacy of Mike Coward. Geological Society, London, Special Publications, 272, 419-436.

Sepehr, M., Cosgrove, J. W. \& Moieni, M. 2006. The impact of cover rock rheology on the style of folding in the Zagros fold-thrust belt. Tectonophysics, $427,265-281$.

Sherkati, S. \& Letouzey, J. 2004. Variation of structural style and basin evolution in the central Zagros (Izeh zone and Dezful Embayment), Iran. Marine and Petroleum Geology, 21, 535-554.

Sherkati, S., Molinaro, M., Frizon de Lamotte, D. \& Letouzey, J. 2005. Detachment folding in the Central and Eastern Zagros fold-belt (Iran): Salt mobility, multiple detachments and late basement control. Journal of Structural Geology, 27, 1680-1696.

Sherkati, S., Letouzey, J. \& Frizon de Lamotte, D. 2006. Central Zagros fold-thrust belt (Iran): New insights from seismic data, field observation, and sandbox modeling. Tectonics, 25, doi: 10.1029/2004TC001766.

Silva, P. G., Goy, J. L., Zazo, C. \& Bardaji, T. 2003. Fault-generated mountain fronts in southeast Spain: Geomorphologic assessment of tectonic and seismic activity. Geomorphology, 50, 203-225.

Stephenson, B., Koopman, A., Hillgartner, H., McQuillan, H., Bourne, S., Noad, J. \& Rawnsley, K. 2007. Structural and stratigraphic controls on fold-related fracturing in the Zagros Mountains, Iran: Implications for reservoir development. In: Lonergan, L., Jolly, R. J. H., Rawnsley, K. \& Sanderson, D. J. (eds.) Fractured Reservoirs, Geological Society, London, Special Publications, 270, 1-21.

Summerfield, M. A. 1991. Global Geomorphology. Prentice Hall, Harlow.
Summers, J. M. 1979. An experimental and theoretical investigation of multilayer fold development. PhD thesis, Imperial College, London.

Suppe, J. 1983. Geometry and kinematics of faultbend folding. American Journal of Science, 283, 684-721.

Suppe, J. \& Connors, C. 1999. Shear fault-bend and fault-propagation folding; New theory and examples. Geological Society of America, 1999 annual meeting. Geological Society of America, Abstracts with Programs, 31, 237.

Talebian, M. \& Jackson, J. 2004. A reappraisal of earthquake focal mechanisms and active shortening in the Zagros Mountains of Iran. Geological Journal International, 156, 506-526.

Vita-Finzi, C. 2001. Neotectonics at the Arabian plate margins. Journal of Structural Geology, 23, 521-530.

Vita-Finzi, C. 2005. Serial deformation. Proceedings of the Geologists' Association, 116, 293-300.

Walker, R. T. 2006. A remote sensing study of active folding and faulting in southern Kerman province, S.E. Iran. Journal of Structural Geology, 28, 654-668.

Walpersdorp, A. 2006. Difference in the GPS deformation pattern of north and central Zagros (Iran). Geophysical Journal International, 167, 1077-1088.

Walsh, J. J., Nicol, A. \& Childs, C. 2002. An alternative model for the growth of faults. Journal of Structural Geology, 24, 1669-1675.

Whittaker, A. C., Cowie, P. A., Attal, M., Tucker, G. E. \& Roberts, G. P. 2007. Bedrock channel adjustment to tectonic forcing: Implications for predicting river incision rates. Geology, 35, 103-106.

Wilkerson, M. S., Medwedeff, D. A. \& Marshak, S. 1991. Geometrical modeling of fault-related folds - a pseudo-3-dimensional approach. Journal of Structural Geology, 13, 801-812.

Wiltschko, D. V. \& Chapple, W. M. 1977. Flow of weak rocks in Appalachian plateau folds. AAPG Bulletin, 61, 653-670. 